\title{
ВПЛИВ ЗАПАЛЬНИХ ЦИТОКІНІВ НА ПЕРЕБІГ ХРОНІЧНОГО ОБСТРУКТИВНОГО ЗАХВОРЮВАННЯ ЛЕГЕНЬ
}

\section{Вплив запальних цитокінів на перебіг хронічного обструктивного захворювання легень}

Л. Б. Винниченко, В. Ф. Орловський, А. В. Жаркова, Н. В. Деміхова, Т. О. Якуба

Сумський державний університет

Вступ. Хронічне обструктивне захворювання легень (ХОЗЛ) $є$ однією 3 провідних проблем охорони здоров'я в усьому світі, що зумовлено значною поширеністю даної патології, досить високими показниками інвалідності й смертності, а також великими економічними втратами. Це захворювання є найчастішою причиною інвалідизачії і летальності серед усіх легеневих захворювань. За прогнозами експертів, у 2020 р. смертність від ХОЗЛ мала вийти на третє місце.

Мета дослідження - вивчити вплив запальних цитокінів на перебіг хронічного обструктивного захворювання легень (ХОЗЛ).

Матеріали і методи. Загальна кількість досліджуваних склала 146 осіб, які були зіставлені за віком та статтю. Першу групу склали 100 пацієнтів, хворих на ХОЗЛ (II ступінь (cm.) бронхообструкції мали 38 хворих, III cm.43 хворих, IV cm.-19 хворих). Другу групу склали відносно здорові куриі зі стажем куріння $\geq 10$ пачко/років (24 особи). Третю групу склали здорові некурці чоловіки, зі стажем куріння $\leq 1$ пачко/років (22 особи). Хворим було проведено спірометричне дослідження; аналіз крові на біомаркери запалення (БЗ), а саме - лейкоцити, С-реактивний білок (СРБ), інтерлейкін-6 (IL6), інтерлейкін-8 (IL8), фрібриноген; комп'ютерна томографрія легень; виміри індексу маси тіла (IMT); тест mMRC, опитувальники SGRQ ma CAT. Рівень біомаркерів запалення (БЗ) у хворих на ХОЗЛ порівнювався з такими у здорових курців з нормальними показниками спірометрії та у тих, хто не курить. Для аналізу статистичної значущості відмінностей між групами використовували тести краскела - Уолліса. Достовірність відмінностей між кількісними ознаками із ненормальним розподілом проводили за допомогою непараметричного парного U-критерію Манна - Уітні. Зіставлення якісних показників проводили з використанням $\chi^{2}$-критерію з поправкою Йєйтса. В усіх випадках достовірними вважали відмінності при р<0,05.

Результати. Рівень БЗ, а саме - лейкоцити, СРБ, IL6 та фрібриногену є статистично вищим $(p<0,001)$ у пацієнтів із ХОЗЛ, ніж у курців з нормальною фуннкцією легень і тих, хто не курить, тоді як рівень IL8 вищий у групі курців без ХОЗЛ (p<0,001). Середній рівень СРБ,
Influence of inflammatory cytokines on the course of chronic obstructive pulmonary disease

L. B. Vynnychenko, V. F. Orlovskiy, A. V. Zharkova, N. V. Demikhova, T. O. Yakuba

Sumy State University

e-mail: luvynnychenko@gmail.com

Summary. Chronic obstructive pulmonary disease $(C O P D)$ is one of the leading health problems worldwide, due to the high prevalence of this pathology, fairly high rates of disability and mortality, as well as large economic losses. This disease is the most common cause of disability and mortality among all lung diseases. According to experts, in 2020, mortality from COPD should have come in third place.

The aim of the study - to learn the effect of inflammatory cytokines on the course of chronic obstructive pulmonary disease (COPD).

Materials and Methods: The total number of examined patients was 146 people, who were compared by age and sex. Group 1 consisted of 100 patients with COPD (38 patients had stage II bronchoobstruction, stage III 43 patients, stage IV - 19 patients). Group 2 consisted of relatively healthy smokers with smoking experience $\geq$ 10 packs/year (24 people). Group 3 consisted of healthy non-smoking men with smoking experience $\leq 1$ pack/year (22 people). Patients underwent spirometric examination; blood test for biomarkers of inflammation (BI), namely leukocytes, C-reactive protein (CRP), interleukin-6 (IL-6), interleukin-8 (IL-8), fibrinogen; computed tomography of the lungs; body mass index (BMI) measurements; mMRC test, SGRQ and CAT questionnaires. The level of $\mathrm{BI}$ in patients with COPD was compared with those in healthy smokers with normal spirometry and non-smokers. Kraskel-Wallis tests were used to analyze the statistical significance of differences between groups. Significance of differences between quantitative traits with abnormal distribution was performed using the nonparametric pair $U$ Mann-Whitney test. Comparison of qualitative indicators was performed using the criterion $x 2$ with Yates correction. In all cases, differences at $p<0.05$ were considered significant.

Results. The results showed that the level of $B I$, namely leukocytes, CRP, IL-6 and fibrinogen is statistically higher $(p<0.001)$ in patients with COPD than in smokers with normal lung function and non-smokers, while the level of IL-8 is higher in the group of smokers without COPD $(p<0,001)$. The mean levels of CRP, IL-6, and fibrinogen 
IL6 та фрібриногену майже не відрізняється між курцями і екс-курцями в межах досліджуваних груп (ДГ), тоді як рівень IL8 у теперішніх курців статистично вищий порівняно з тими пацієнтами, які кинули курити, як у хворих на ХОЗЛ $(p<0,01)$, так і в групі курців з нормальними показниками спірометрії $(p<0,001)$. Відсоток осіб з підвищеним рівнем БЗ був значно вищим в першій групі, порівняно з другою (70 й 62 \% відповідно, $p<0,05$ ), та в другій порівняно з третьою (62 й $22 \%$ відповідно, $p<0,001)$. Відсоток хворих, які мали підвищення двох i більше Б3, був також статистично вищим в групі ХОЗЛ порівняно з курцями без ХОЗЛ $(p<0,05)$ та з некурцями $(p<0,001)$. Спостерігається прямий кореляційний зв'язок між вираженням БЗ та cm. бронхообструкції ХОЗЛ (r=0,39, p<0,05). У хворих на ХОЗЛ встановлені прямі позитивні кореляційні взаємовідношення між вираженням 53 та стажем куріння $(r=0,82 ; p<0,05)$, вираженням задишки за шкалою $\operatorname{mMRC}(r=0,62 ; p<0,05)$, наявністю супутньої патології $(r=0,51 ; p<0,05)$, частотою емфріземи легень та загострень протягом року ( $r=0,82$ та $r=0,89$ відповідно; $p<0,05)$.

Висновки. Отримані результати дозволяють розглядати БЗ у пацієнтів із ХОЗЛ як фрактор, що модифрікує розвиток патології.

Ключові слова: хронічне обструктивне захворювання легень; біомаркери запалення; цитокіни; системне запалення; індекс маси тіла.

\section{ВСТУП}

Хронічне обструктивне захворювання легень (ХОЗЛ) є однією 3 провідних проблем охорони здоров'я в усьому світі, що зумовлено значною поширеністю даної патології, досить високими показниками інвалідності й смертності, а також великими економічними втратами. Це захворювання $€$ найчастішою причиною інвалідизації і летальності серед усіх легеневих захворювань. За прогнозами експертів, у 2020 р., смертність від ХОЗЛ мала вийти на третє місце [1-4].

Традиційно діагностика і визначення тяжкості перебігу захворювання опирається на дані спірометрії [5]. Керуючись показником об'єму фрорсованого видиху за першу секунду (ОФВ $)$, що $€$ «золотим стандартом» у діагностиці ХОЗЛ, ми маємо можливість контролювати перебіг захворювання. Проте як показує практика, пацієнти з однаковими показниками ОФВ ${ }_{1}$ можуть мати різні патологічні зміни, клінічні прояви, у тому числі різну кількість загострень протягом року та різний ступінь вираження емфіземи легень [6,7]. Це спонукає до пошуку більш чутливих маркерів щодо оцінки тяжкості й прогресування ХОЗЛ, які мають більш точно відображати активність та ступінь вираження запалення, структурні зміни, стадію захворювання, вплив на якість життя і прогноз.

Згідно з даними літератури, останніми роками намітилась тенденція до вивчення специфічних маркерів запалення різних патологічних станів, у were almost indistinguishable between smokers and exsmokers within the study groups, whereas the level of IL-8 in current smokers was statistically higher than in those who quit smoking as in patients with COPD $(p<0.01)$ and in the group of smokers with normal spirometry $(p<0.001)$. The percentage of people with elevated levels of $\mathrm{BI}$ was significantly higher in group 1 compared to group 2 (70\% and $62 \%$, respectively, $p<0.05)$ and in group 2 compared to group 3 (62\% and $22 \%$, respectively, $p<0.001)$. The percentage of patients who had an increase in 2 or more $B I$ was also statistically higher in the group of COPD compared with smokers without COPD $(p<0.05)$ and non-smokers ( $p$ $<0.001$ ). There is a direct correlation between the severity of $B I$ and bronchoobstruction of COPD $(r=0.39, p<0.05)$. In patients with COPD, there were direct positive correlations between the severity of $B I$ and smoking experience $(r=0.82$; $p<0.05$ ), the severity of shortness of breath on the mMRC scale $(r=0.62 ; p<0.05)$, the presence of concomitant pathology $(r=0.51 ; p<0.05)$, the frequency of pulmonary emphysema and exacerbations during the year $(r=0.82$ and $r=0.89$, respectively; $p<0.05$ ).

Conclusions. The obtained results allow us to consider $B I$ in patients with COPD as a factor that modifies the development of pathology.

Key words: chronic obstructive pulmonary disease; biomarkers of inflammation; cytokines; systemic inflammation; body mass index.

тому числі й при ХОЗЛ. Запалення дихальних шляхів $€$ основним компонентом у патогенезі останнього. Воно характеризується різними клітинними профрілями, що можуть відображати різні підгрупи ХОЗЛ залежно від характеру запалення і рівня медіаторів запалення [8, 9]. Проте існує багато суперечливих досліджень щодо вираження запального процесу залежно від стадії ХОЗЛ. За даними одних дослідників існує прямий зв'язок між стадією ХОЗЛ та ступенем системного запалення $[8,10,11]$. Спостерігається збільшення рівня IL1ß, IL2, IL6, IL8 та СРБ пропорційно зростанню тяжкості ХОЗЛ, що пояснюється більш вираженою антигенною стимуляцією при тяжкому перебігу хвороби. Водночас, у роботах інших авторів показано, що при 4 стадії ХОЗЛ спостерігаються найменші показники IL [1113]. При вивченні концентрації СРБ у пацієнтів із різними стадіями ХОЗЛ було виявлено найбільші значення при 1 та 2 стадіях, тоді як у хворих на 3 та 4 стадіях хвороби спостерігались практично нормальні величини $[14,15]$. Цей фракт автори пояснюють зниженням синтезу цитокінів унаслідок виснаження білково-енергетичнихресурсів йімунологічною недостатністю, зниженням фрагоцитарного індексу нейтрофрілів при тяжчому перебігу захворювання [13, 15]. В інших дослідженнях показано, що при стабільній ХОЗЛ рівень системного запалення майже не відрізняється між стадіями хвороби, разом 3 тим, як при загостренні ХОЗЛ спостерігається більш високий рівень IL6, IL8, СРБ і фрібриногену 
[8]. Суперечливі дані щодо цього питання потребують детального вивчення, що і визначило мету нашого дослідження.

Метою дослідженя було вивчити вплив запальних цитокінів на перебіг хронічного обструктивного захворювання легень (ХОЗЛ).

\section{МАТЕРІАЛИ I МЕТОДИ}

Пацієнтів для дослідження підібрали в терапевтичному та пульмонологічному відділеннях КУСМКЛ № 1 м. Суми. В основну та дві контрольні групи учасники підбирались за методом «випадокконтроль» таким чином, щоб групи були зіставні за віком. Для статистичної обробки було включено загальну кількість досліджуваних - 146 осіб чоловічої статі. Першу групу склали 100 хворих на ХОЗЛ (з ІІ ступенем бронхообструкції - 38 хворих, III - 43 хворих, IV - 19 хворих) віком від 35 до 85 років (середній вік $(63,1 \pm 2,9)$ року). Діагноз ХОЗЛ встановлювали на основі наказу МО3 України № 555 від 27.06.2013 р. та глобальних рекомендацій GOLD - 2019 [7]. Критеріями виключення для усіхпацієнтів були:тяжкий дефріцит $\alpha_{1}$-антитрипсину (визначався експрес-методом лише у пацієнтів із підозрою на дефріцит фрерменту) [16], хірургічні втручання на легенях в анамнезі, зловживання алкоголем та наркотичними речовинами, супутня патологія в стадії декомпенсації. Другу групу склали здорові (щодо ХОЗЛ) курці зі стажем куріння $\geq 10$ пачко-років (24 особи) віком від 48 до 81 років (середній вік - $(60,5 \pm 1,7)$ року). Третю групу склали здорові некурці зі стажем куріння $\leq 1,0$ пачко-років (22 особи) (середній вік - $(58,3 \pm 1,8)$ року).

На початку та в кінці дослідження були виконані клінічний та біохімічний аналізи крові на виявлення Б3, а саме: лейкоцитів, СРБ, IL6, IL8, фрібриногену. Вміст IL визначали в сироватці крові методом ІФА-аналізу 3 використанням якісної та кількісної методики тест-системи «Цитокін». Хворим було проведено спірометричне дослідження за загальноприйнятою методикою на апараті «Комплекс спірографрічний - Спіроком», виробник HАУ «XAІ». Визначали ОФВ ємкість легень (ФЖЄЛ), індекс Тифно - ОФВ 1 ФЖЄЛ, максимальну об'ємну швидкість під час видиху на рівні 25 \% ФЖЄЛ (МОС25), 50 \% ФЖЄЛ (MOC 50), 75 \% ФЖЕЛ (МОС75). За допомогою комп'ютерної томографії (КТ) легень визначали ступінь тяжкості емфіземи легень. Кожне зображення КТ було ретроспективно візуально оцінено, використовуючи систему класиорікації Флейшнера [17]. Вираження емфріземи оцінювали кількісно, використовуючи відсотковий об'єм легенів, де спостерігаються ділянки зниженої щільності - $950 \mathrm{HU}$ або менше (LAA-950) [18,19]. Усі особи проходили тест mMRC (Modified Medical Research Council -
Модифікована шкала Медичної Дослідної Ради) для оцінки диспное та заповнювали опитувальник SGRQ (St George's respiratory Questionnaire - респіраторний опитувальник госпіталю Святого Георгія) для контролю якості життя. Хворі на ХОЗЛ також заповнювали опитувальник CAT (COPD Assessment Test - тест 3 оцінки ХозЛ) для контролю симптомів перебігу захворювання. Усі хворі на ХОЗЛ приймали симбікорт від 160/4,5 мкг до 320/9,0 мкг інгаляційно двічі на добу, сальбутамол ( якості препарату невідкладної допомоги. У разі недостатньої еорективності вказаних препаратів додавали М-холінолітик тривалої дії - «Тіотропію бромід» («Спірива») по 1 інгаляційній дозі (18 мкг) щоденно.

Статистичний аналіз. Якісні показники представлені у вигляді абсолютної кількості (n) та відсотків (\%). Для аналізу статистичної значущості відмінностей між групами використовували тести Краскела - Уолліса. Кількісні значення 3 нормальним розподілом були представлені у вигляді середньої арифрметичної (М) та середнього квадратичного відхилення (б). Кількісні значення, що мали ненормальний розподіл, були представлені у вигляді медіани (Ме) та інтерквартильного (25$75 \%$ розмаху. Достовірність відмінностей між кількісними ознаками із ненормальним розподілом проводили за допомогою непараметричного парного U критерію Манна - Уїтні. Зіставлення якісних показників проводили з використанням критерію $\chi^{2}$ з поправкою Йєйтса. Логістичну регресію використовували для дослідження фракторів, що сприяють стійкому системному запаленню у хворих на ХОЗЛ. В усіх випадках достовірними вважали відмінності при $р<0,05$.

\section{РЕЗУЛЬТАТИ Й ОБГОВОРЕННЯ}

Базова характеристика пацієнтів та осіб контрольних груп представлена в таблиці 1, дані якої показують, що особи третьої групи, порівняно з іншими, дещо молодші за віком, проте ця різниця не $€$ статистично значимою.

Індекс маси тіла (IMT) статистично не відрізняється в дослідних групах. У пацієнтів із ХОЗЛ було виражене обмеження швидкості повітряного потоку i, як і очікувалося, підвищена частота загострень. Частота серцево-судинних захворювань дещо вища у хворих на ХОЗЛ, порівняно з курцями без ХОЗЛ, проте ця різниця статистично не значима, але статистично вища порівняно $з$ пацієнтами третьої групи (відповідно 47,0; 44,8 та 18,2 \%). Ознаки емфріземи легень були виявлені у 70 \% хворих на ХОЗЛ, 8,3 \% курців без ХОЗЛ. У пацієнтів групи контролю емсрізема легень не спостерігалась. Якість життя дослідних груп статистично вищою була в третій та другій групах порівняно 3 хво- 
Таблиця 1. Загальна характеристика дослідних груп

\begin{tabular}{|c|c|c|c|c|c|c|}
\hline \multirow[b]{2}{*}{ Показник } & \multirow[b]{2}{*}{$\begin{array}{c}\text { ХОЗЛ } \\
(n=100)\end{array}$} & \multirow[b]{2}{*}{$\begin{array}{l}\text { Курці ( } \geq 10 \text { пач- } \\
\text { ко/роки) }(\mathrm{n}=24)\end{array}$} & \multirow[b]{2}{*}{$\begin{array}{l}\text { Некурці } \\
(n=22)\end{array}$} & \multicolumn{3}{|c|}{$p$} \\
\hline & & & & 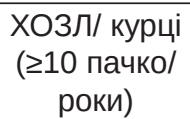 & $\begin{array}{c}\text { хОзл/ } \\
\text { некурці }\end{array}$ & $\begin{array}{c}\text { курці } \\
\text { ( } \geq 10 \text { пачко/ } \\
\text { роки)/некурці }\end{array}$ \\
\hline Вік, роки & $63,1 \pm 2,9$ & $60,5 \pm 1,7$ & $58,3 \pm 1,8$ & $>0,05$ & $>0,05$ & $>0,05$ \\
\hline Стаж куріння, пачко/роки & $43,9 \pm 5,4$ & $40,8 \pm 3,6$ & $\leq 1,0$ & $>0,05$ & $<0,001$ & $<0,001$ \\
\hline $\mathrm{IMT}, \mathrm{Kr} / \mathrm{M}^{2}$ & $27,9 \pm 1,2$ & $27,1 \pm 0,8$ & $26,2 \pm 0,7$ & $>0,05$ & $>0,05$ & $>0,05$ \\
\hline Tест mMRC & $1,8 \pm 0,8$ & $0,4 \pm 0,1$ & $0,1 \pm 0,1$ & $<0,001$ & $<0,001$ & $>0,05$ \\
\hline Tест SGRQ-C & $48,7 \pm 17,4$ & $9,6 \pm 10,6$ & $5,2 \pm 5,9$ & $<0,001$ & $<0,001$ & $>0,05$ \\
\hline Тест СAT & $25,8 \pm 17,4$ & 0,0 & 0,0 & & & \\
\hline $\begin{array}{l}\text { Частота загострень } \\
\text { (за останній рік) }\end{array}$ & $3,3 \pm 0,7$ & 0,0 & 0,0 & - & - & - \\
\hline $\mathrm{CC} 3, \%$ & $47,0 \pm 1,7$ & $44,8 \pm 0,5$ & $18,2 \pm 0,3$ & $<0,1$ & $<0,001$ & $<0,01$ \\
\hline Емфрізема легенів, \% & 70,0 & 8,3 & 0 & $<0,001$ & $<0,001$ & $<0,05$ \\
\hline ОФВ 1 /ЖЄЛ, \% & $43,5 \pm 12,4$ & $77,6 \pm 5,7$ & $81,1 \pm 5,2$ & $<0,001$ & $<0,001$ & $>0,05$ \\
\hline ОФВ 1, мл/с & $1389,1 \pm 124$ & $3257,6 \pm 106$ & $3371,9 \pm 113$ & $<0,001$ & $<0,001$ & $>0,05$ \\
\hline $\begin{array}{l}\text { ОФВ }{ }_{1} \text { (тест } 3 \text { бронходи- } \\
\text { лататором), мл }\end{array}$ & $9,4 \pm 0,6$ & $5,3 \pm 0,4$ & $2,9 \pm 0,1$ & $<0,05$ & $<0,05$ & $>0,05$ \\
\hline Лейкоцити, х10*9/л & $7,8[6,2-9,4]$ & $7,1[6,0-8,5]$ & $5,9[5,1-7,5]$ & $<0,001$ & $<0,001$ & $<0,001$ \\
\hline СРБ, мг/л & $3,1[1,4-7,2]$ & $1,3[0,7-2,9]$ & $0,8[0,5-1,7]$ & $<0,001$ & $<0,001$ & $<0,001$ \\
\hline IL6, пг/мл & $1,6[1,4-7,2]$ & $0,6[0,3-1,3]$ & $0,4[0,2-0,9]$ & $<0,001$ & $<0,001$ & $<0,01$ \\
\hline IL8, пг/мл & $7,1[3,1-13,5]$ & $7,8[3,9-5,3]$ & $4,2[2,1-7,4]$ & $<0,01$ & $<0,001$ & $<0,001$ \\
\hline Фібриноген, г/л & $4,4[3,92-6,2]$ & $3,7[3,4-4,5]$ & $3,1[2,5-4,2]$ & $<0,001$ & $<0,001$ & $<0,001$ \\
\hline
\end{tabular}

Примітка. p - достовірність розбіжностей між групами хворих.

рими на ХОЗЛ (p<0,001). Курці без ХОЗЛ та особи третьої групи мали нормальні показники спірометpіï.

Згідно $з$ даними таблиці 1 щодо Б3, рівень лейкоцитів, CPБ, IL6 та фрібриногену є статистично вищим $(p<0,001)$ у пацієнтів із ХОЗЛ, ніж у курців 3 нормальною функцією легень, і тих, хто не курить, тоді як рівень IL8 вищий у групі курців без ХОЗЛ $(p<0,001)$. Отже, можна припустити, що на рівень лейкоцитів, CPБ, IL6 та фрібриногену фрактор куріння не впливає. Щоб підтвердити наше припущення, встановити взаємозв'язок між фрактором куріння та БЗ, у кожній із груп ці показники вираховувались окремо для тих, хто продовжує курити (курці), й тих, хто припинив курити (екскурці) (табл. 2).
Для зниження похибки та отримання точного результату було вичислено та використано значення медіани та інтерквартильного розмаху, тобто 25 \% найменших та найбільших значень не було враховано у загальний.

Згідно 3 даними таблиці 2, середній рівень CPБ, IL6 та фрібриногену майже не відрізняється між курцями і екс-курцями в межах дГ, тоді як рівень IL8 у теперішніх курців статистично вищий, порівняно з тими пацієнтами, які кинули курити, як у хворих на ХОЗЛ (p<0,01), так і в групі курців із нормальними показниками спірометрії ( $p<0,001)$. Отже, за даними наших досліджень, рівень СРБ, IL6 і фрібриногену не залежить від впливу тютюнового диму і є маркером загального запального процесу, характерному для ХОЗЛ, тоді як показник IL8

Таблиця 2. Медіана [інтерквартильний розмах] запальних біомаркерів, визначені на початку дослідження у пацієнтів із хронічним обструктивним захворюванням легень та у курців із нормальною функцією легень

\begin{tabular}{|c|c|c|c|c|c|c|}
\hline \multirow[b]{2}{*}{ Показник } & \multicolumn{3}{|c|}{ ХОЗЛ } & \multicolumn{3}{|c|}{ Курці ( $\geq 10$ пачко/роки) } \\
\hline & $\begin{array}{l}\text { курці } \\
(n=52)\end{array}$ & $\begin{array}{c}\text { колишні курці } \\
(n=48)\end{array}$ & $p$ & $\begin{array}{l}\text { курці } \\
(n=17)\end{array}$ & $\begin{array}{c}\text { колишні курці } \\
(\mathrm{n}=7)\end{array}$ & $p$ \\
\hline Лейкоцити, х10\%/л & $8,2[2,8]$ & $7,4[2,8]$ & $<0,05$ & $7,2[2,8]$ & $6,9[2,1]$ & $<0,05$ \\
\hline СРБ, мг/л & $3,1[6,0]$ & $3,0[5,4]$ & $>0,05$ & $1,3[2,0]$ & $1,2[2,0]$ & $>0,05$ \\
\hline IL6, пг/мл & $1,6[2,4]$ & $1,5[2,4]$ & $>0,05$ & $0,6[1,0]$ & $0,5[0,9]$ & $>0,05$ \\
\hline IL8, пг/Мл & $7,4[11,1]$ & $6,7[9,2]$ & $<0,01$ & $9,0[15,8]$ & $5,6[7,8]$ & $<0,001$ \\
\hline Фібриноген, г/л & $4,4[1,3]$ & $4,5[1,2]$ & $>0,05$ & $3,7[9,0]$ & $3,8[8,1]$ & $>0,05$ \\
\hline
\end{tabular}

Примітка. р - достовірність розбіжностей між групами. 
більшою мірою характеризує фрактор куріння. Загальна кількість лейкоцитів теж статистично вищою була у курців, порівняно з тими, хто не курить в обох дослідних групах (р<0,05). У таблиці 3 відображено відсоток пацієнтів кожної дГ із підвищенням окремого біомаркера запалення.

Група ХОЗЛ складалась із статистично більшого відсотка хворих із підвищеним рівнем лейкоцитів, CРБ, IL6 та фрібриногену, порівняно з групою курців без ХОЗЛ $(p<0,05)$ та з некурцями $(p<0,001)$, тоді як відсоток пацієнтів, які мали підвищений рівень IL8 був вищим у групі курців без ХОЗЛ
( $p<0,001)$. Спостерігається тенденція до зростання рівня Б3, а саме кількості лейкоцитів, CPБ, IL6 та фрібриногену відповідно зі зростанням ступеня бронхообструкції ХОЗЛ, проте це не є характерним для IL8 (табл. 4).

Водночас, було виявлено, що в кожній групі був певний відсоток пацієнтів з абсолютно нормальними значеннями БЗ.

На рисунку 1 відображено 3 групи пацієнтів, кожну з них поділено на 5 підгруп. Перша позначена «0» - це підгрупа пацієнтів, у яких жоден 3 п'яти Б3 не був підвищений. Друга, позначена «1»

Таблиця 3. Відсоток осіб кожної дослідної групи з підвищенням окремих біомаркерів запалення

\begin{tabular}{|c|c|c|c|c|c|c|}
\hline \multirow[b]{2}{*}{ Показник } & \multirow[b]{2}{*}{$\begin{array}{c}\text { ХОЗЛ, } \\
\mathrm{n}=100(\%)\end{array}$} & \multirow[b]{2}{*}{$\begin{array}{c}\text { Курці ( } \geq 10 \text { пач- } \\
\text { ко/роки), } \\
\text { n=24 (\%) }\end{array}$} & \multirow[b]{2}{*}{$\begin{array}{l}\text { Некурці, } \\
\text { n=22 (\%) }\end{array}$} & \multicolumn{3}{|c|}{$p$} \\
\hline & & & & $\begin{array}{c}\text { ХОЗЛ/ } \\
\text { курці ( } \geq 10 \text { пач- } \\
\text { ко/роки) }\end{array}$ & $\begin{array}{l}\text { ХОЗЛ/ не- } \\
\text { курці }\end{array}$ & $\begin{array}{c}\text { курці ( } \geq 10 \text { пачко/ } \\
\text { роки)/ некурці }\end{array}$ \\
\hline Лейкоцити & $28(28)$ & $5(21)$ & $1(4,5)$ & $<0,05$ & $<0,001$ & $<0,001$ \\
\hline СРБ & $21(21)$ & $2(8)$ & 0 & $<0,05$ & $<0,001$ & $<0,05$ \\
\hline IL6 & $29(29)$ & $2(8)$ & 0 & $<0,05$ & $<0,001$ & $<0,001$ \\
\hline IL8 & $16(16)$ & $6(25)$ & $1(4,5)$ & $<0,001$ & $<0,001$ & $<0,001$ \\
\hline Фібриноген & $26(26)$ & $2(8)$ & $1(4,5)$ & $<0,05$ & $<0,001$ & $<0,01$ \\
\hline
\end{tabular}

Примітка. р - достовірність розбіжностей між групами хворих.

Таблиця 4. Медіана [інтерквартильний розмах] окремих біомаркерів запалення залежно від ступеня порушення легеневої фрункції у пацієнтів із хронічним обструктивним захворюванням легень

\begin{tabular}{|c|c|c|c|c|c|c|}
\hline \multirow[b]{2}{*}{ Показник } & \multirow[b]{2}{*}{$\begin{array}{c}\text { ХОЗЛ } \\
\text { II ст. }(n=38)\end{array}$} & \multirow[b]{2}{*}{$\begin{array}{c}\text { ХОЗЛ } \\
\text { III ст. }(n=43)\end{array}$} & \multirow[b]{2}{*}{$\begin{array}{c}\text { ХОЗЛ } \\
\text { IV ст. }(n=19)\end{array}$} & \multicolumn{3}{|c|}{$p$} \\
\hline & & & & $\begin{array}{c}\text { ХОЗЛ } \\
\text { ІІ ст./ } \\
\text { ХОЗЛ ІІІ ст. }\end{array}$ & $\begin{array}{c}\text { ХОЗЛ } \\
\text { III ст./ } \\
\text { ХОЗЛ ІV ст. }\end{array}$ & $\begin{array}{c}\text { ХОЗЛ } \\
\text { IV ст./ } \\
\text { ХОЗЛ IV ст. }\end{array}$ \\
\hline Лейкоцити, ×10\%/л & $7,4[2,7]$ & $7,7[2,5]$ & $8,2[3,2]$ & $>0,05$ & $<0,003$ & $>0,05$ \\
\hline СРБ, Мг/л & $2,7[4,8]$ & $3,4[6,1]$ & $3,6[7,6]$ & $<0,01$ & $>0,05$ & $<0,01$ \\
\hline IL6, пг/мл & $1,5[2,2]$ & $1,7[2,5]$ & $2,1[3,6]$ & $<0,01$ & $<0,001$ & $>0,05$ \\
\hline IL8, пг/мл & $7,8[10,1]$ & $7,0[10,5]$ & $6,0[9,3]$ & $<0,05$ & $<0,001$ & $<0,001$ \\
\hline Фібриноген, г/л & $4,2[1,2]$ & $4,4[1,3]$ & $4,9[1,5]$ & $<0,05$ & $<0,001$ & $<0,001$ \\
\hline
\end{tabular}

Примітка. p - достовірність розбіжностей між групами хворих.

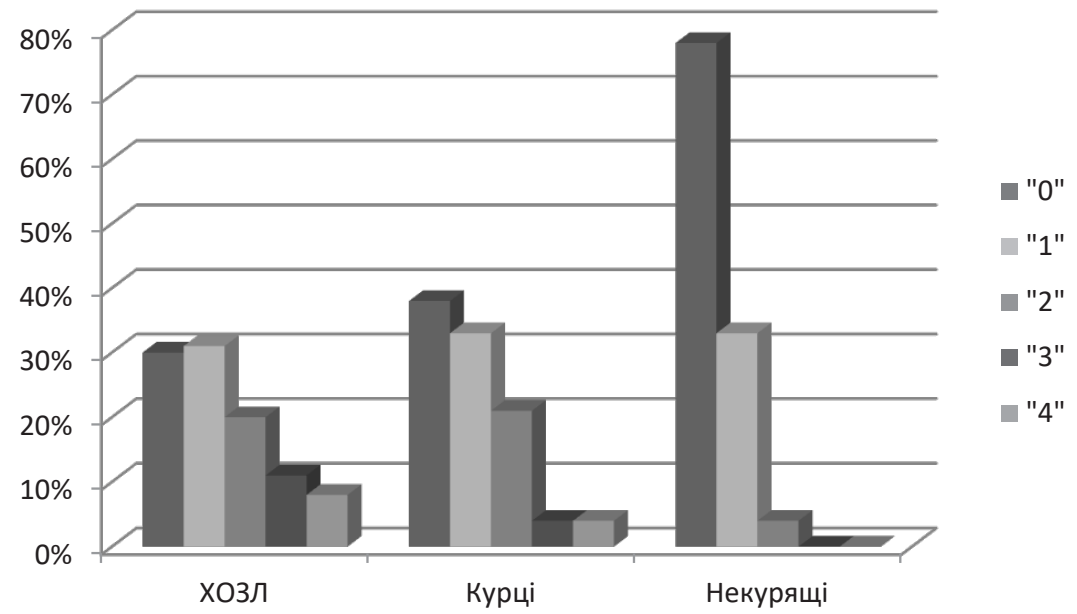

Рис. 1. Розподіл частоти біомаркерів запалення з нормальними та підвищеними значеннями в межах кожної дослідної групи. 
- це підгрупа пацієнтів, у яких лише один із БЗ був підвищеним. У третій підгрупі «2» було виявлено збільшення двох Б3, у четвертій «3» - трьох. П'яту підгрупу, позначену як «4+», склали пацієнти, у яких було підвищено чотири або всі п'ять БЗ. За даними нашого дослідження «1» Б3 спостерігали у 31 (31\%) хворих на ХОЗЛ, у 8 (33 \%) курців без ХОЗЛ та у 4 (18\%) некурців, «2» - у 20 (20\%), 5 (21\%) та 1 (4 \%) осіб відповідно, «3» - у 11 (11\%), 1 (4 \%) та у $0 \%$, «4» - у 8 (8 \%), 1(4 \%) та $0 \%$ відповідно до ДГ. Отже, у 17 (78 \% ) осіб, які не курять, у 9 (38 \%) курців без ознак ХОЗЛ й у 30 (30\%) хворих на ХОЗЛ не визначалось підвищення жодного із Б3. Відсоток осіб з підвищеним рівнем БЗ був значно вищим в першій групі, порівняно з другою (70 й $62 \%$ відповідно, р<0,05), та в другій, порівняно 3 третьою (62 й 22 \% відповідно, р<0,001). Відсоток хворих, які мали кількість БЗ 2 і більше, був також статистично вищим у групі ХОЗЛ порівняно 3 курцями без ХОЗЛ $(p<0,05)$ та 3 некурцями $(p<0,001)$. Таким чином, у курців запалення більш виражене, порівняно з особами, які не курять, але найбільші показники зберігаються у пацієнтів із ХОЗЛ (проти курців і тих, хто не курить).
Якщо порівняти вираження СЗ у групі хворих на ХОЗЛ залежно від ступеня порушення легеневої функції, як це показано на рисунку 2, можна зробити висновок, що існує прямий кореляційний зв'язок між вираженням С3 та ступенем бронхообструкції ( $r=0,39$, p<0,05). Відсоток пацієнтів зі збільшеною кількістю БЗ зростає відповідно до ступеня бронхообструкції хвороби. Так, два і більше Б3 мали 10 (27\%) хворих на ХОЗЛ II ст., 17 (40 \%) - III ст. та 12 (63 \%) - IV ст. Один Б3 визначався у 13 (34\%), 13 (30\%) та у 5 (26 \%) осіб II-IV ст. відповідно. Жодного БЗ не вдалося визначити у 15 (39\%), 13 (30\%) та у 2 (11\%) пацієнтів II-IV ст. відповідно.

У групі хворих на ХОЗЛ встановлені прямі позитивні кореляційні взаємовідношення між вираженням С3 та стажем куріння ( $r=0,82 ; p<0,05)$, вираженням задишки за шкалою $\mathrm{mMRC}(r=0,62 ; p<0,05)$, наявністю супутньої патології ( $r=0,51 ; p<0,05)$, частотою емфіземи легень та загострень протягом року ( $r=0,82$ та r=0,89 відповідно; p<0,05) (табл. 5).

Проте ми не спостерігали кореляційних зв'язків між Б3 та якістю життя пацієнтів. Отримані результати дозволяють розглядати БЗ у пацієнтів із ХОЗЛ як фрактор, що модифікує розвиток патології.

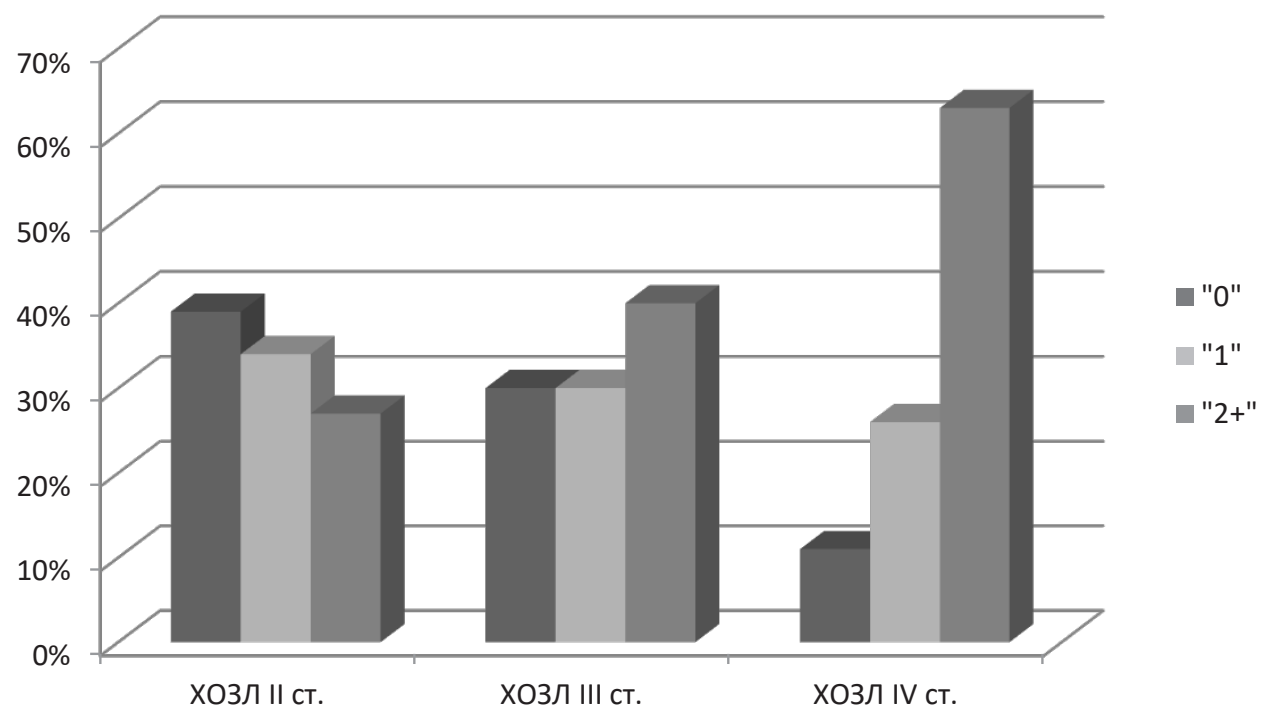

Рис. 2. Розподіл частоти біомаркерів запалення з нормальними та підвищеними значеннями залежно від ступеня порушення легеневої фрункції у пацієнтів із хронічним обструктивним захворюванням легень.

Таблиця 5. Взаємозв'язок між ступенем вираження системного запалення у пацієнтів із хронічним обструктивним захворюванням легень та стажем куріння, ступенем вираження задишки (за шкалою mMRC), наявністю супутньої патології, частотою загострення протягом року

\begin{tabular}{l|c|c|c}
\hline \multicolumn{1}{c|}{ Показник } & 0 & $1+$ & $3+$ \\
\hline Стаж куріння (пачко/роки) & $17,23 \pm 3,2$ & $36,19 \pm 5,8$ & $48,52 \pm 4,6$ \\
\hline Тест mMRC & $0,8 \pm 0,9$ & $1,5 \pm 1,1$ & $1,8 \pm 0,4$ \\
\hline Тест SGRQ-C & $46,7 \pm 32,4$ & $45,3 \pm 30,8$ & $47,5 \pm 30,7$ \\
\hline Супутня патологія, \% & 19,6 & 37,2 & 43,8 \\
\hline Емсрізема легень, \% & 0 & 23 & 77 \\
\hline Частота загострень (за останній рік) & $0,3 \pm 0,1$ & $1,8 \pm 0,78$ & $4,8 \pm 0,86$ \\
\hline
\end{tabular}




\section{висновки}

1. $78 \%$ пацієнтів із ХОЗЛ мають підвищений рівень Б3, таких, як лейкоцити, СРБ, фрібриноген, IL6 та IL8.

2. Рівень лейкоцитів, CPБ, IL6 та фрібриногену $€$ статистично вищим ( $<<0,001)$ у пацієнтів із ХОЗЛ, ніж у курців з нормальною фрункцією легень, і тих, хто не курить.

3. Рівень IL8 вищий у групі курців із нормальною фрункцією легень порівняно з хворими на ХОЗЛ $(p<0,001)$.

4. У хворих на ХОЗЛ спостерігається прямий позитивний кореляційний зв'язок між вираженням

\section{СПИСОК ЛІТЕРАТУРИ}

1. Фещенко Ю. І. Бронхіальна астма, хронічне обструктивне захворіння легень: перспективна глобальна стратегія ведення, новітні методи діагностики, сучасні підходи до терапії / Ю. І. Фещенко // Астма та алергія. 2015. - № 4. - С. 38-42.

2. Фенотип ХОЗЛ - шлях до персоніфрікованої медицини XXI століття / Т. С. Оспанова, Ж. Д. Семидоцька, І. А. Чернякова [та ін.] // Східноєвропейський журнал внутрішньої та сімейної медицини. Пульмонологія. 2017. - № 1. - C. 95-101.

3. Фещенко Ю. І. Хронічне обструктивне захоплення легену: етіологія, патогенез, класиорікація, діагностика, терапія (проект національної угоди) матеріальні з їзду / Ю.І.Фещенко, Л.О.Яшина, О.Я.Дзюблик // Український пульмонологічний журнал. - 2013. - № 3. - С. 7-12.

4. Cigarette smoking promotes inflammation in patients with COPD by affecting the polarization and survival of Th/Tregs through up-regulation of muscarinic receptor / M. Zhang, Y. Wan, Y. Jin [et al.] // PLoS ONE. - 2014. No. 9 (11). - C. e112350. DOI: 10.1371/journal.pone.0112350.

5. Айсанов 3. Р. Спирометрия для диагностики и оценки терапевтической эффрективности при хронической обструктивной болезни легких в первичной медицинской помощи / 3. Р. Айсанов, А. В. Черняк, Е. Н. Калманова // Российская пульмонология. - 2014. - № 5. - C. 101-110. https://doi.org/10.18093/0869-01892014-0-5-101-110

6. Погребняк О. О. Огляд сучасних рекомендацій 3 ведені хворих із хронічних обструктивних захворів легену: підсумки Міжнародного конгресу «Профрілактика. Антиейджінг» / О. О. Погребняк // Ліки України. - 2015. № $7 .-$ C.193.

7. Global strategy for prevention, diagnosis and management of COPD 2019 / D. Singh, A. Agusti, A. Anzueto [et al.] // Eur. Respir. J. - 2019. DOI:10.1183/13993003.00164-2019.

8. Дудка П. Ф. Гемореологічні і імунні порушення та можливості їх корекції у хворих на хронічне обструктивне закріплення легень / П. Ф. Дудка, Д. В. Добрянський, Р. І. Ільницький // Молодій вчений. - 2014. - № 2 (05). C. 157-160. http://nbuv.gov.ua/UJRN/molv_2014_2(05)_39.

9. Clusters of cmorbidities based on validated objective measurements and systemic inflammation in patients with chronic obstructive pulmonary disease / L. E. Vanfleteren,
Б3 та ступенем порушення легеневої фрункції $(r=0,39, p<0,05)$.

5. У хворих на ХОЗЛ встановлені прямі позитивні кореляційні взаємовідношення між вираженням Б3 та стажем куріння ( $r=0,82 ; p<0,05)$, вираженням задишки за шкалою $\mathrm{mMRC}(\mathrm{r}=0,62$; $p<0,05)$, наявністю супутньої патології ( $r=0,51$; $p<0,05)$, частотою емфріземи легень та загострень протягом року ( $r=0,82$ та $r=0,89$ відповідно; $\mathrm{p}<0,05)$.

6. Вплив системного запалення на перебіг ХОЗЛ із коморбідною патологією потребує подальшого вивчення.

M. A. Spruit, M. Groenen [et al.] // American Journal of Respiratory and Critical Care Medicine. - 2013. - No. 7. P. 728-735.

10. Кочубей О. А. Цитокіни, як первинні медіатори в регуляції реакції запалення / О. А. Кочубей // Загальнотерапевтична практика: нові технології та міждисциплінарні питання : матеріали науково-практичної конференції з міжнародної участі. - Харків, 2013. - С. 164.

11. Маркеры системного воспаления и эндотелиальной диссрункции при хронической обструктивной болезни легких / М. Г. Мамаєва, И. В. Демко, Я. И. Вериго [и др.] // Сибирское медицинское образование. - 2014. - № 1. - С. 12-19.

12. Матвієнко Ю. О. Біомаркери та їх місце у патогенезі хронічного обструктивного захоплення легень / Ю. О. Матвієнко // Астма та алергія. - 2016. - № 3. - С.1-6.

13. Маркери системного запалення в хворих на хронічне обструктивне закріплення легень / М. І. Гуменюк, В. І. Ігнатьєва, Ю. А. Матвієнко [та ін.] // Український пульмонологічний журнал. - 2014. - № 3. - С. 33-36.

14. Cytokine response to the 6 -min walk test in individuals with different degrees of COPD / G. P. Dorneles, P. Vianna, D. Del Duca Lima [et al.] // Clin. Respir. J. - 2015. - Vol. 10 (3).

15. Interleukin-6 and interleukin-8 blood levels' poor association with the severity and clinical profile of exsmokers with COPD / M. R. de Moraes, A. C. da Costa, S. Corrêa Kde [et al.] // Int. J. Chron. Obstruct. Pulmon. Dis. - 2014. - No. 9. - P. 735-743. DOI: 10.2147/COPD.S64135.

16. Капот Б. И. Експресс-метод выявления антитрипсина и антихемо-трипсини в крови / Б. И. Капот // Лабораторне дело. - 1981. - № 4. - С. 27-29.

17. Mac Mahon. Guidelines for management of incidental pulmonary nodules detected on CT / Mac Mahon // Radiology. - 2017. DOI10.1148/radiol.2017161659.

18. A quantification of the lung surface area in emphysema using computed tomography / H. O. Coxson, R. M. Rogers, K. P. Whittall [et al.] // Am. J. Respir. Crit. Care Med. - 1999. - No. 159 (3). - P. 851-856.

19. Pertseva T. A. Relation between clinical and anthropometric data and systemic inflammation in patients with COPD / T. A. Pertseva, D. S. Mykhailychenko // Медичні перспективи. - 2015. - № 4. - C. 16-22. DOI: https://doi. org/10.26641/2307-0404.2015.4.56128 


\section{REFERENCES}

1. Feschenko Yul. [Bronchial asthma, chronic obstructive pulmonary disease: a promising global strategy, the latest diagnostic methods, modern approaches to therapy] Astma ta alergiya. 2015;4: 38-42. Ukrainian.

2. Ospanova TS, Semidotskaya ZhD, Chernyakova IA, Pionova EN, Trifonova NS. [The COPD phenotype the path to personalized medicine of the XXI century] Shidnoevropeyskyi zhurnal vnutrishnoi ta simeinoi medytsyny. Pulmonolohiia. 2017;1: 95-101. Ukrainian.

3. Feschenko Yul, Yashina LO, Dzyublik OYa. [Chronic obstructive pulmonary disease: etiology, pathogenesis, classification, diagnosis, therapy (draft national agreement) material congress]. Ukrainskyi pulmonolohichnyi zhurnal. 2013;3: 7-12. Ukrainian.

4. Zhang M, Wan Y, Jin Y, Xin JB, Zhang JC, Xiong XZ, et al. Cigarette smoking promotes inflammation in patients with COPD by affecting the polarization and survival of Th/Tregs through up-regulation of muscarinic receptor. PLoS ONE. 2014;9(11): e112350. DOI: 10.1371/journal. pone.0112350

5. Aysanov ZR, Chernyak AV, Kalmanova EN. [Spirometry for diagnosis and therapeutic efficacy evaluation in chronic obstructive pulmonary disease in primary care]. Ros pulmonol. 2014;(5): 101-10. Available from: https://doi. org/10.18093/0869-0189-2014-0-5-101-110. Russian.

6. Pogrebnyak OO. [Review of current guidelines for the management of patients with chronic obstructive pulmonary disease: the results of the International Congress "Prevention. Anti-aging"]. Liky Ukrainy. 2015;7 (193). Ukrainian.

7. Singh D, Agusti A, Anzueto A, Barnes PJ, Bourbeau J, Celli BR, et al. Global strategy for prevention, diagnosis and management of COPD 2019. Eur Respir J. 2019. DOI:10.1183/13993003.00164-2019

8. DudkaPF, DobryanskiyDV, IlnitskyRI. [Hemoreological and immune disorders and the possibility of their correction in patients with chronic obstructive pulmonary fixation]. Molodyi vchenyi. 2014;2(05): 157-160. Available from: http://nbuv.gov.ua/UJRN/molv_2014_2(05)_39. Ukrainian.

9. Vanfleteren LE, Spruit MA, Groenen M, Gaffron S, van Empel VP, Bruijnzeel PL, et al. Clusters of comorbidities based on validated objective measurements and systemic inflammation in patients with chronic obstructive pulmonary disease. American Journal of Respiratory and Critical Care Medicine. 2013;7: 728-35.
10. Kochubey OA. [Cytokines, as primary mediators in the regulation of the reaction of inflammation]. General Therapeutic Practice: New Technologies and Interdisciplinary Issues, materials of the scientific-practical conference with international participation. Kharkiv; 2013. Ukrainian.

11. Mamaeva MG, Demko IV, Verigo Yal, KraposhinaAYu, Solovieva IA, Hendogina VT. [Markers of systemic inflammation and endothelial dysfunction in chronic obstructive pulmonary disease] Sibirskoe meditsinskoe obrazovanie. 2014;1: 12-9. Russian.

12. Matvienko YuO. [Biomarkers and their place in the pathogenesis of chronic obstructive pulmonary disease]. Astma ta alerhiia. 2016;3: 1-6. Ukrainian.

13. Gumeniuk MI, Ignatieva VI, Matviienko YuA, Iliinska IF, Harchenko-Sevrukova GS. [Markers of systemic inflammation in patients with chronic obstructive pulmonary fixation]. Ukrainskyi pulmonolohichnyi zhurnal. 2014;3: 336. Ukrainian.

14. Dorneles GP, Vianna P, Del Duca Lima D, Galant L, Dias AS, Chies JA, et al. Cytokine response to the 6-min walk test in individuals with different degrees of COPD. Clin Respir J. 2015;10(3). Available from: https://onlinelibrary. wiley.com/doi/abs/10.1111/crj.12221

15. de Moraes MR, da Costa AC, Corrêa Kde S, Junqueira-Kipnis AP, Rabahi MF. Interleukin-6 and interleukin-8 blood levels' poor association with the severity and clinical profile of ex-smokers with COPD. Int J Chron Obstruct Pulmon Dis. 2014;9: 735-43. DOI: 10.2147/COPD. S64135

16. Hood BI. [Express method for detecting antitrypsin and antihemo-trypsin in the blood]. Laboratornoye delo. 1981;4: 27-9. Russian.

17. Guidelines for management of incidental pulmonary nodules detected on CT images: From the Fleischner Society. Radiology. 2017. DOI10.1148/radiol.2017161659.

18. Coxson HO, Rogers RM, Whittall KP, D'yachkova Y, Paré PD, Sciurba FC, et al. A quantification of the lung surface area in emphysema using computed tomography. Am J Respir Crit Care Med. 1999;159(3): 851-6.

19. Pertseva TA. Mykhailychenko DS. Relation between clinical and anthropometric data and systemic inflammation in patients with COPD. Medychni perspektyvy. 2015;4; $16-$ 22. DOI: https://doi.org/10.26641/2307-0404.2015.4.56128.

Отримано 03.02.21
ISSN 2706-6282(print)

ISSN 2706-6290(online) 